\title{
Rhodobacter sphaeroides Extract Improves Glucose Homeostasis in Streptozotocin-Induced Diabetic Mice
}

\author{
Chih-Chiang Wang ${ }^{1,2}$, Wen-Sheng Liu ${ }^{1,3}$, Fu-Hsin Chang ${ }^{3}$, Pei-Yi Tsai ${ }^{4}$, Ming-Kai Tsai ${ }^{2}$, Jeng-Chuan Shiang ${ }^{2}$ and Zhi-Hong Wen ${ }^{1 *}$
}

${ }^{1}$ Department of Marine Biotechnology and Resources, National Sun Yat-sen University, Kaohsiung, Taiwan

${ }^{2}$ Department of Medicine, Kaohsiung Armed Forces General Hospital, Kaohsiung, Taiwan

${ }^{3}$ Asia-Pacific Biotech Developing, Inc. Kaohsiung, Taiwan

${ }^{4}$ Department of Pharmacology, Institute for Drug Evaluation Platform, Development Center for Biotechnology, Taiwan

\begin{abstract}
Insulin resistance is one of the most important mechanisms of diabetes mellitus. Anti-oxidants had been proved to improve insulin resistance. However, the direct relation between anti-oxidants and glucose homeostasis is still elusive. Recently, we found that Lycogen ${ }^{\mathrm{TM}}$ (extracts of Rhodobacter sphaeroides WL-APD911) has lycopene-like activity. Furthermore, Lycogen ${ }^{T M}$ showed more potent anti-oxidative effect and less cytotoxicity than lycopene. To evaluate the effect of Lycogen ${ }^{\mathrm{TM}}$ on blood glucose levels, STZ-induced diabetic mice were randomly divided into four groups: (1) diabetes control group; (2) diabetes+Lycogen ${ }^{\mathrm{TM}} 50 \mathrm{mg} / \mathrm{kg}$; (3) diabetes+Lycogen ${ }^{\mathrm{TM}} 100 \mathrm{mg} / \mathrm{kg}$; and (4) diabetes+Lycogen ${ }^{\mathrm{TM}} 200 \mathrm{mg} / \mathrm{kg}$. After 7 days of treatment, the blood glucose level in the Lycogen ${ }^{\mathrm{TM}} 200 \mathrm{mg} / \mathrm{kg}$ group was significantly lower than the disease control group $(p<0.01)$. In the oral glucose tolerance test, the blood glucose level was significantly lower in the Lycogen ${ }^{\mathrm{TM}} 200 \mathrm{mg} / \mathrm{kg}$ group than the disease control group $(p<0.05)$. Our results confirmed that Lycogen ${ }^{\mathrm{TM}}$, a potent anti-oxidant, can significantly lower blood glucose levels in a diabetic mice model.
\end{abstract}

Keywords: Rhodobacter sphaeroides; Lycogentm; Anti-Oxidants; Diabetes mellitus

\section{Introduction}

Diabetes mellitus (DM) continues to be a major burden on society globally. The International Diabetes Federation has predicted that the global burden of diabetes will increase to 552 million by 2030. In spite of newer and effective treatment, glucose control remains relatively poor in a subset of subjects diagnosed and treated with diabetes. Therefore, extensive research is still being performed to develop potential antidiabetic agents [1]. Reduction of action of insulin to activate the glucose transport system in skeletal muscle (referred to as "insulin resistance") is the most important mechanism of DM. Oxidative stress has been increasingly recognized as a common underlying mechanism of insulin resistance [2-6]. Recent studies support this connection that the direct exposure of mammalian skeletal muscle to an oxidant stress results in the stimulation of mitogen-activated protein kinase (MAPK) and that MAPK signaling is mechanistically associated with the diminished insulin-dependent stimulation of insulin signaling and glucose transport [7-10]. Thus, strategies to prevent and ameliorate oxidative stress have become important in the treatment of diabetes. However, the association between anti-oxidants and glycemic control was still elusive in previous observational studies [11-16].

Bacteria can produce some compounds in response to their environment. These compounds are widely used in pharmaceutical applications. Carotenoids, responsible for pigments in plants, deep green vegetables and yellow fruits, possess antioxidant properties. Carotenoids are also biosynthesized in photosynthetic bacteria such as Rhodobacter sphaeroides [17] with the function of photoprotection [18]. Recently, we extract a novel fractionate $\left(\right.$ Lycogen $\left.^{\mathrm{TM}}\right)$ from transformant Rhodobacter sphaeroides WL-APD911 [19,20]. Lycogen $^{\mathrm{TM}}$, which contained $\zeta$-carotene, neurosporene, spheroidenone and methoxyneurosporene according to nuclear magnetic resonance spectroscopy analysis, has anti-oxidative activity. $\zeta$-Carotene is the precursor of neurosporene, which is the precursor of lycopene. Furthermore, Lycogen ${ }^{\mathrm{TM}}$ showed more potent anti-oxidative effects and less cytotoxicity than lycopene in our study. Therefore, we aimed to study the effect of Lycogen ${ }^{\mathrm{TM}}$ on blood glucose levels.

\section{Materials and Methods}

\section{Lycogen $^{\mathrm{TM}}$}

Rhodobacter sphaeroides WL-APD911 (DSM 25056) was a new strain, isolated from mutants using chemical mutagenesis (Rhodobacter sphaeroides; Bioresource Collection and Research (BCRC), Hsinchu, Taiwan). The R. sphaeroides WL-APD911 was cultured in broth. After harvesting, the bacterial broth was centrifuged and washed with ethanol. The bacterial residue is extracted with acetone and then centrifuged by $7500 \mathrm{rpm}$ for $5 \mathrm{~min}$. The supernatant is filtered through filter paper and a $0.2 \mu \mathrm{m}$ filter into a round-bottomed flask. The color of the final supernatant is dark red. Acetone is removed completely in an oven at $55^{\circ} \mathrm{C}$. The extract of R. sphaeroides WL-APD911 was named Lycogen $^{\mathrm{TM}}$. The Lycogen ${ }^{\mathrm{TM}}$ is available from Asia-Pacific Biotech Developing, Inc. (Kaohsiung, Taiwan).

\section{DPPH radical-scavenging activity}

The free radical-scavenging activity was determined using the method described by Braca et al. [21]. Freshly prepared DPPH solution, lycopene and Lycogen ${ }^{\mathrm{TM}}$ extract at various concentrations $(25 \mu \mathrm{M}, 50 \mu \mathrm{M}$ and $100 \mu \mathrm{M})$ were mixed and incubated at $37^{\circ} \mathrm{C}$ for 30 min. The absorbance at $517 \mathrm{~nm}$ was determined, and the percentage of

*Corresponding author: Dr. Zhi-Hong Wen, Department of Marine Biotechnology and Resources, National Sun Yat-sen University, 70 Lienhai Rd., Kaohsiung 80424, Taiwan, Tel: +886-7-5252000; E-mail: ndmcndmcndmc@gmail.com

Received December 16, 2013; Accepted January 06, 2014; Published January 09, 2014

Citation: Wang CC, Liu WS, Chang FH, Tsai PY, Tsai MK, et al. (2014) Rhodobacter sphaeroides Extract Improves Glucose Homeostasis in Streptozotocin-Induced Diabetic Mice. J Microb Biochem Technol 6: 038-042. doi:10.4172/19485948.1000119

Copyright: $\odot 2014$ Wang CC, et al. This is an open-access article distributed under the terms of the Creative Commons Attribution License, which permits unrestricted use, distribution, and reproduction in any medium, provided the original author and source are credited 
Citation: Wang CC, Liu WS, Chang FH, Tsai PY, Tsai MK, et al. (2014) Rhodobacter sphaeroides Extract Improves Glucose Homeostasis in Streptozotocin-Induced Diabetic Mice. J Microb Biochem Technol 6: 038-042. doi:10.4172/1948-5948.1000119

inhibition activity was calculated as $[(\mathrm{A} 0-\mathrm{A} 1) / \mathrm{A} 0] \mathrm{x} 100$, where $\mathrm{A} 0$ is the absorbance of the control, and A1 is the absorbance of the extract/ standard. The inhibition curves were constructed, and IC50 values were obtained.

\section{Cytotoxicity assessment}

The effects of Lycogen ${ }^{\mathrm{TM}}$ on the cell viability of Hs68 cells (human fibroblast cells, purchased from Bioresource Collection and Research Center) were evaluated by 3-(4,5-dimethylthiazol-2-yl)-2,5-diphenyl tetrazolium bromide (MTT) assay. For the MTT assay, various concentrations of Lycogen ${ }^{\mathrm{TM}}$ and lycopene were separately added to the medium (Dulbecco's Modified Eagle's Medium) $24 \mathrm{~h}$ before the cell viability assay. In brief, MTT solution was added to each well, and the plates were incubated at $37^{\circ} \mathrm{C}$ for $4 \mathrm{~h}$. The formazan product was then dissolved in $100 \mu \mathrm{DMSO}$ at $37^{\circ} \mathrm{C}$ for $30 \mathrm{~min}$, and the absorbance at $570 \mathrm{~nm}$ was measured with a microplate reader. Cell cytotoxicity was determined and expressed as the percentage of viable cells of the total number of cells counted. The values are the means $\pm S D(n \geq 3)$ for each treatment.

\section{Experimental animals}

Seven-week-old C57BL/6 male mice were obtained from a supply company (BioLASCO Co., Ltd., Taipei, Taiwan). The animals were housed in stainless steel cages at $25 \pm 2^{\circ} \mathrm{C}$ with a relative humidity range of $40 \%-70 \%$ and an alternating 12 -hour light-dark cycle, and they were fed standard laboratory chow and water. The experimental protocol was approved by the Laboratory Animal Care and Use Committee (IACUC) of the Development Center for Biotechnology.

\section{Establishment of experimental diabetes model}

Diabetes was induced by the intraperitoneal injection of STZ (50 $\mathrm{mg} / \mathrm{kg}$; Sigma, USA) in freshly prepared citrate buffer $(0.1 \mathrm{M}, \mathrm{pH} 4.5)$ for four consecutive days. The blank control group was intraperitoneally injected with an equivalent amount of buffer. Diabetic mice were confirmed by measuring the $4 \mathrm{~h}$ fasting blood glucose levels from the tail vein at one week after injection with STZ. Animals with a blood glucose level above $250 \mathrm{mg} / \mathrm{dl}$ were considered to be diabetic and included in the experiment. The serum insulin level was also detected to verify the diagnosis of diabetes.

\section{Oral glucose tolerance test (OGTT)}

After $4 \mathrm{~h}$ of fasting, the basal blood glucose level was measured in test mice. Lycogen ${ }^{\mathrm{TM}}$ was orally administered to each group, and 30 min later, the mice were fed glucose $(1.5 \mathrm{~g} / \mathrm{kg})$ orally. The blood glucose level was detected at 15, 30, 60, 90, and 120 min after feeding.

\section{Statistical analysis}

The results were expressed as the mean+standard error (mean \pm SE.). A one-way ANOVA was used to test the difference between groups. If $\mathrm{P}<0.05$, Dunnett's multiple-range t-test was used to identify the difference between the diabetes group and control group.

\section{Materials and Instruments}

The materials and instruments included $15 \mathrm{ml}$ centrifuge tubes (Corning, USA), a centrifuge (ALC PK131R, Italy), a blood glucose meter (glucometer ACCU-CHEK advantage II, Roche Diagnostics, USA), blood glucose test paper (glucose test Comic books, strips ACCU-CHEK advantage II, Roche Diagnostics, USA), microcentrifuge tubes (SSI and USA), streptozotocin (Sigma, USA), sodium citrate
(Sigma, USA), citric acid (Sigma, USA), 1-ml syringes (Terumo, the Philippines), a mouse insulin ELISA kit (cat. \# 10-1247-01, Mercodia, Sweden), DPPH (Sigma, USA), and an MTT assay kit (Tosoh, Tokyo, Japan).

\section{Results}

\section{Anti-oxidative activity and cytotoxicity assessment}

In the DPPH test, Lycogen ${ }^{\mathrm{TM}}$ showed more potent anti-oxidative activity than Lycopene, especially at higher concentrations (Figure 1). The human fibroblast (Hs68) toxicity assessment of Lycogen ${ }^{\mathrm{TM}}$ showed no cytotoxic effects on human fibroblasts at concentrations below 5 $\mu \mathrm{M}$. In contrast to Lycogen ${ }^{\mathrm{TM}}, 0.1 \mu \mathrm{M}$ lycopene showed cell toxicity in human fibroblasts. More significant cell toxicity was found at higher concentrations of lycopene (Figure 2).

\section{Blood glucose and insulin levels}

Diabetic mice were randomly divided into four groups, (1) diabetes control group; (2) diabetes+Lycogen ${ }^{\mathrm{TM}} 50 \mathrm{mg} / \mathrm{kg}$; (3) diabetes+Lycogen ${ }^{\mathrm{TM}} 100 \mathrm{mg} / \mathrm{kg}$; and (4) diabetes+Lycogen ${ }^{\mathrm{TM}} 200 \mathrm{mg} /$ $\mathrm{kg}$. Lycogen was prepared with pumpkin seed oil once a day for 14 consecutive days. The diabetes control group and blank control group, which was only administered pumpkin seed oil, was treated once a day for 14 consecutive days. After the end of the 14-day course, the oral glucose tolerance test (OGTT) was performed on the next day. The experimental design is shown in Table 1.

After injection with STZ, the blood glucose level was significantly increased $(p<0.005)$ in STZ-induced diabetic mice (Figure 3$)$. The success rate of diabetes induction was $92 \%$ (23/25). The serum insulin concentration of STZ-induced diabetic mice was significantly lower than the control group $(\mathrm{P}<0.01)$, which confirmed the successful induction of the diabetic model (Figure 4). Changes in the body weight of the mice during the treatment period are shown in Figure 5. The results showed that Lycogen ${ }^{\mathrm{TM}}$ treatment did not cause weight loss in any group of mice. The blood glucose level after 7 days of Lycogen ${ }^{\mathrm{TM}}$ treatment is shown in Figure 6. Treatment with Lycogen ${ }^{\mathrm{TM}} 200 \mathrm{mg} /$ $\mathrm{kg}$ significantly reduced the blood glucose concentration compared with the disease control group $(\mathrm{P}<0.01)$. No significant difference was found between Lycogen ${ }^{\mathrm{TM}} 50 \mathrm{mg} / \mathrm{kg}, 100 \mathrm{mg} / \mathrm{kg}$ and disease control groups. The oral glucose tolerance test was performed after 14 days of Lycogen ${ }^{\mathrm{TM}}$ administration (Figure 7). At $60 \mathrm{~min}$ after oral glucose loading, the blood glucose level in the Lycogen ${ }^{\mathrm{TM}} 200 \mathrm{mg} / \mathrm{kg}$ group

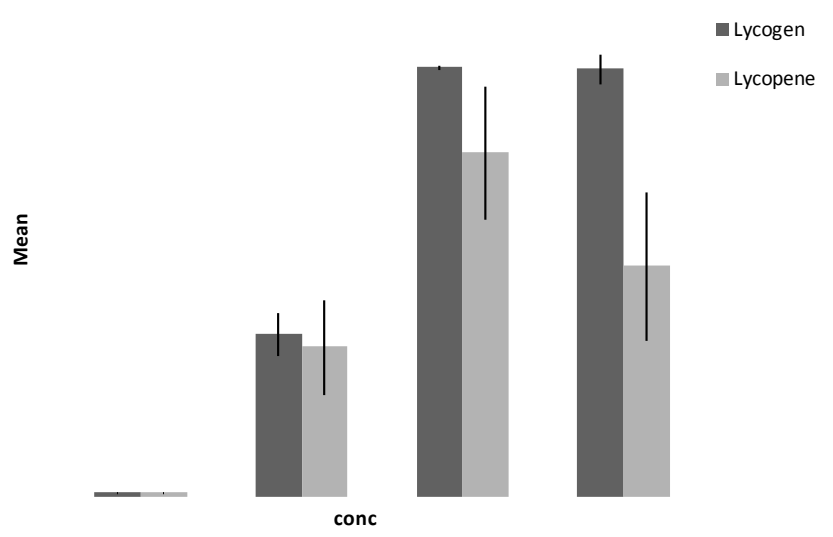

Figure 1: DPPH antioxidant test: Lycogen compared with Lycopene. 
Citation: Wang CC, Liu WS, Chang FH, Tsai PY, Tsai MK, et al. (2014) Rhodobacter sphaeroides Extract Improves Glucose Homeostasis in Streptozotocin-Induced Diabetic Mice. J Microb Biochem Technol 6: 038-042. doi:10.4172/1948-5948.1000119

(A)

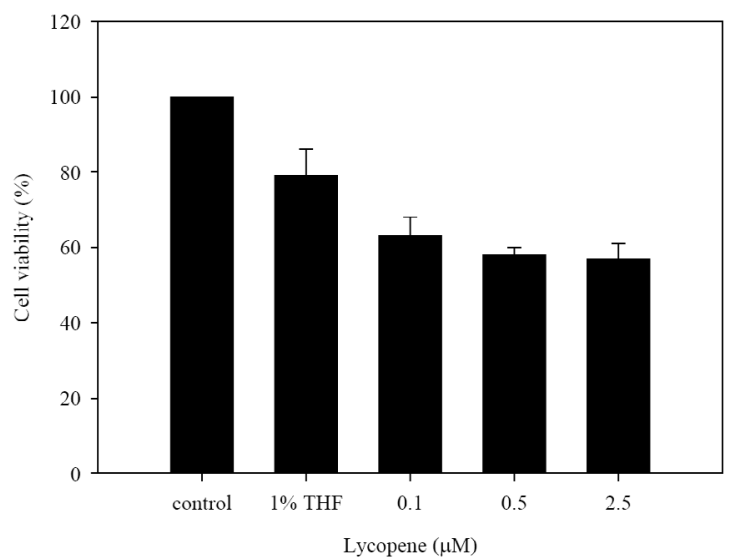

(B)

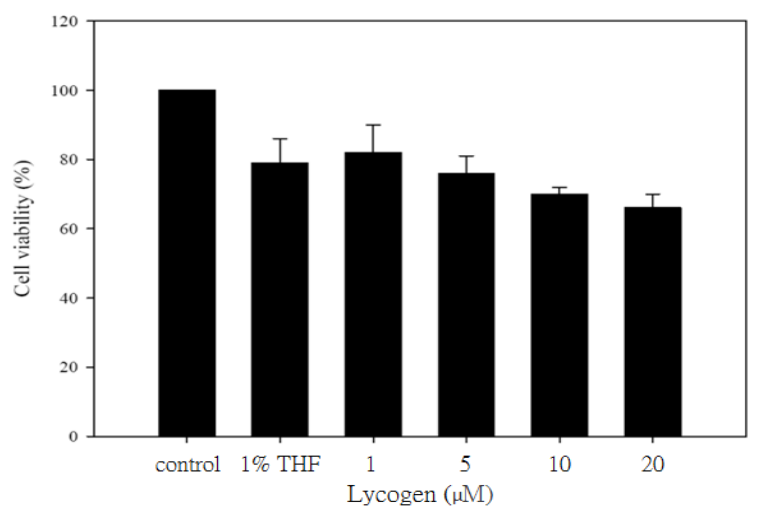

Figure 2: Effects of lycopene and Lycogen on cell cytotoxicity in Hs68 cells (human fibroblast cells). Cells were treated with different concentrations of lycopene(A) or Lycogen (B) for $24 \mathrm{~h}$. THF (tetrahydrofuran; 1\%) served as solvent control for lycopene and Lycogen. Cell cytotoxicity was determined by MTT and expressed as a percentage of viable cells in the total number of cells counted. Values are means $\pm S D(n \geq 3)$ for each treatment.

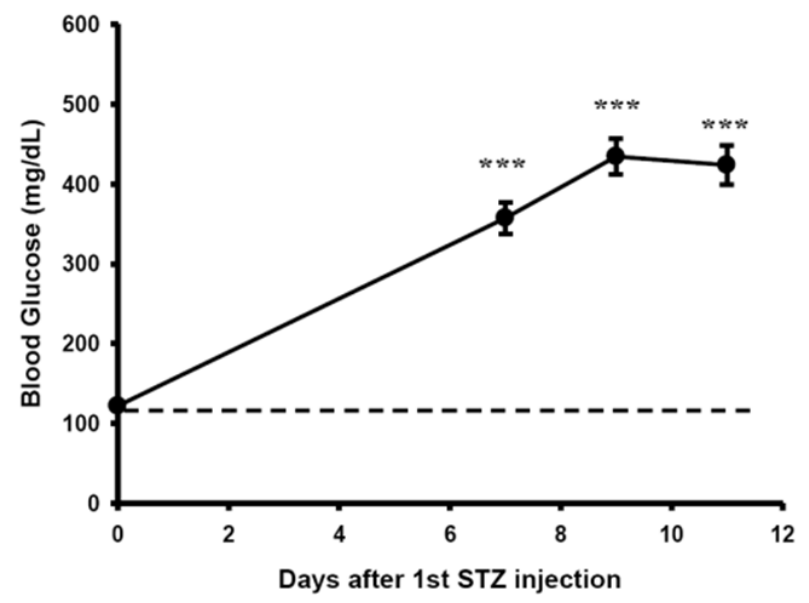

Figure 3: Blood glucose change after STZ injection in mice. The dashed line is the average blood glucose level of the blank control group. ${ }^{* \star *} \mathrm{P}<0.005$ compared with the blank control group.

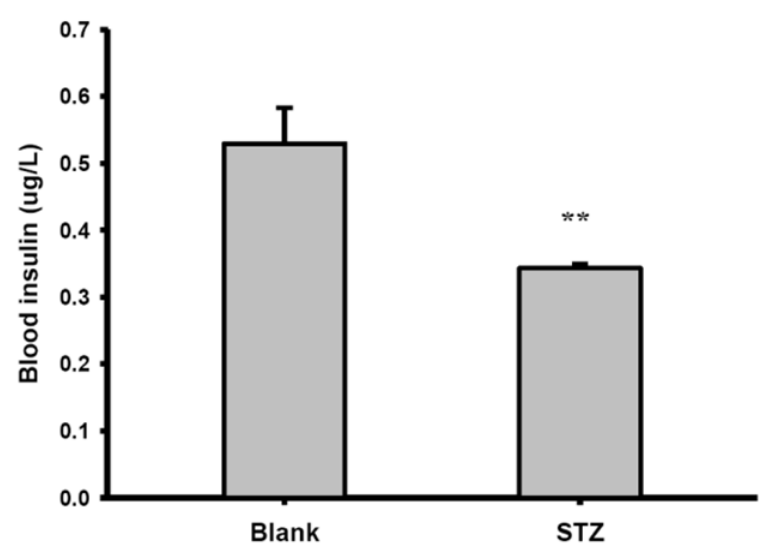

Figure 4: Insulin levels in STZ-induced diabetes mice. ** $\mathrm{P}<0.01$ compared with the blank control group.

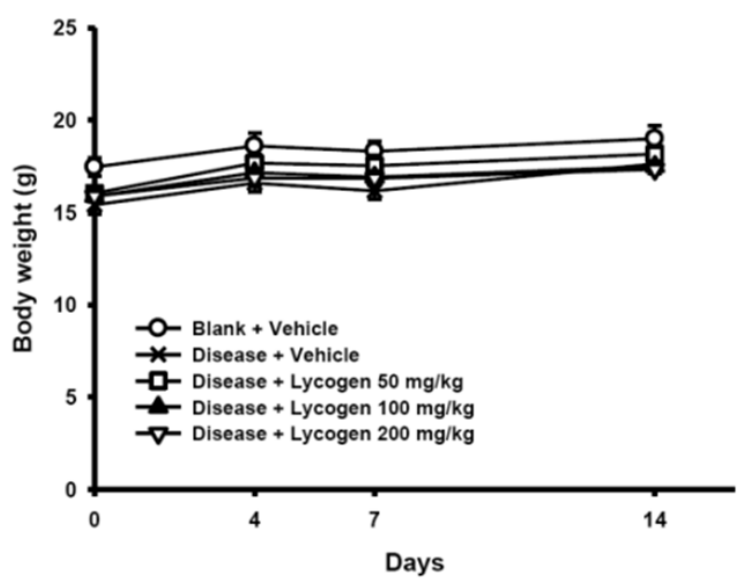

Figure 5: The change of the body weight of the mice in each treatment group during the drug treatment.

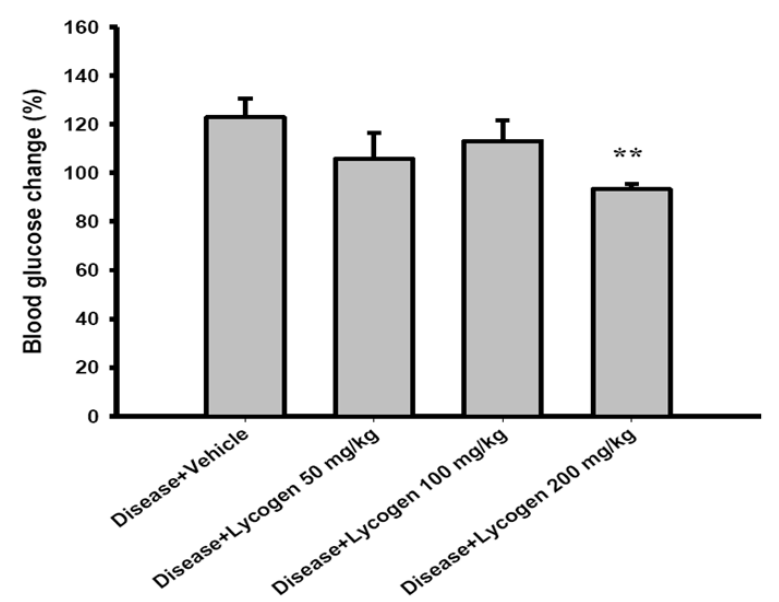

Figure 6: Blood glucose changes in diabetic mice 7 days after treatment Blood glucose change (\%) is calculated as: (7th day glucose level / basal glucose level before treatment) $\times 100 \%$. ${ }^{* *} \mathrm{P}<0.01$ compared with disease control group. 
Citation: Wang CC, Liu WS, Chang FH, Tsai PY, Tsai MK, et al. (2014) Rhodobacter sphaeroides Extract Improves Glucose Homeostasis in Streptozotocin-Induced Diabetic Mice. J Microb Biochem Technol 6: 038-042. doi:10.4172/1948-5948.1000119

was significantly lower than the disease control group $(\mathrm{p}<0.05)$. The insulin level of mice was measured at the same time, and no significant difference was found between any groups (Figure 8).

Homeostatic model assessment (HOMA) is a method used for assessing insulin resistance (IR) using basal (fasting) glucose and insulin concentrations. The HOMA-IR (insulin resistance) index of each group was calculated and shown in Table 2. There was no significant difference in insulin resistance between disease groups (day $0, \mathrm{p}=0.142$ and day $14, \mathrm{p}=0.239)$. When Lycogen ${ }^{\mathrm{TM}} 50$ and $200 \mathrm{mg} / \mathrm{kg}$ were added, there were significant differences in the insulin resistance index between day 0 and day 14 .

\section{Discussion}

Oxidative stress plays an important role in insulin resistance. Moreover, anti-oxidants may be a potential treatment of DM. Rhodobacter sphaeroides extract, Lycogen ${ }^{\mathrm{TM}}$ showed more potent anti-oxidative effects and less cytotoxicity than lycopene. Our data confirmed that Lycogen ${ }^{\mathrm{TM}}$ significantly lowered the blood glucose level in STZ-induced diabetic mice (Figures 6 and 7).

In our study, there was no significant difference in blood insulin levels between the disease control group and Lycogen ${ }^{\mathrm{TM}}$ treatment groups (Figure 8). Thus, the possibility of Lycogen ${ }^{\mathrm{TM}}$ lowering the blood glucose level by increasing insulin release was excluded. In the OGTT, there was no significant difference in the basal glucose level (0 min) between the study groups (Figure 7). Combined with no significant body weight difference between the study groups, this result suggests that it is less likely that Lycogen ${ }^{\mathrm{TM}}$ lowered the blood glucose level through decreasing GI tract absorption. There was a significant difference in the insulin resistance index between day 0 and day 14 in the Lycogen ${ }^{\mathrm{TM}} 50$ and $200 \mathrm{mg} / \mathrm{kg}$ groups (Table 2). Our data was consistent with previous studies, reduced oxidative stress improved insulin resistance in animal models [2-6].

Lycopene, a carotenoid, has been shown to have more potent antioxidant properties than other carotenoids in vitro [22]. In a cross-sectional study, greater dietary lycopene intake was associated with reduced fasting plasma glucose concentrations [23]. Plasma concentrations of lycopene had been shown to have an inverse association with fasting blood glucose [11-15]. However, no significant glucose-lowering effect of lycopene was found in other observational study [16]. The association between lycopene and glycemic control was still elusive in these observational studies.

Lycogen $^{\mathrm{TM}}$ showed more potent anti-oxidative activity and less cytotoxicity than lycopene in this study (Figures 1 and 2). Our results showed that the blood glucose level was significantly lower in the highdose group (Lycogen ${ }^{\mathrm{TM}} 200 \mathrm{mg} / \mathrm{kg}$ ). However, no significant difference was found in the glucose level between the lower dose group and control group (Figures 6 and 7). Glucose-lowering effect of Lycogen ${ }^{\mathrm{TM}}$ was significant in higher dose but not in lower dose. Lycogen ${ }^{\mathrm{TM}}$ improved glycemic control in dose-dependent manner was suspected. This dosedependent relation can explain the inconsistent findings in previous observational studies. In consideration of the dose-dependent effect, the more potent and less toxic Lycogen ${ }^{\mathrm{TM}}$ may be a potential candidate for the development of a new anti-diabetic agent.

Our results confirmed that Lycogen ${ }^{\mathrm{TM}}$, a potent anti-oxidant, can significantly improve insulin resistance and lower blood glucose levels in a diabetic mice model. Further investigation is warranted to clarify its possibility of use in diabetic patients.

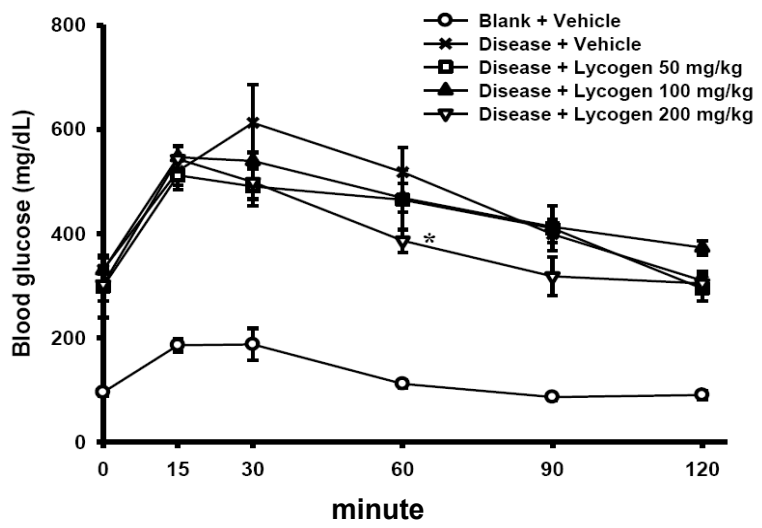

Figure 7: OGTT results of each treatment group. ${ }^{*} \mathrm{P}<0.05$ compared with the disease control group.

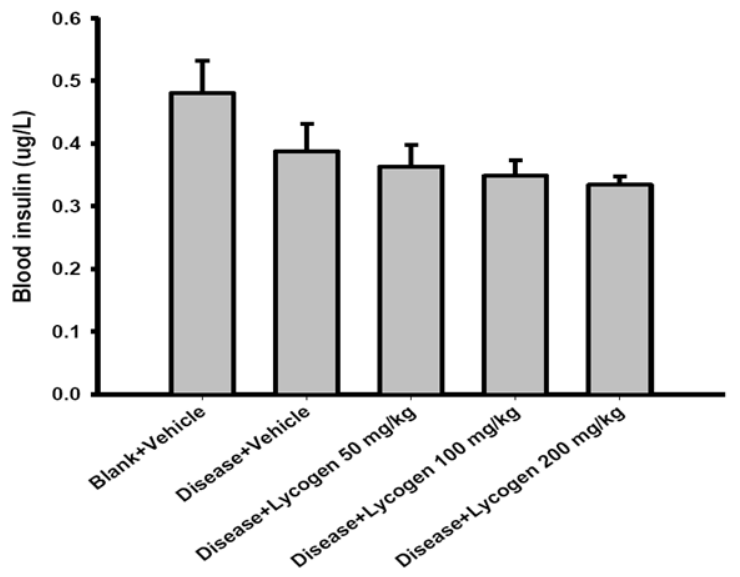

Figure 8: The blood insulin concentration 14 days after treatment.

\begin{tabular}{|c|c|c|c|}
\hline Group & Lycogen Dose & Frequency & Mice number \\
\hline Blank+vehicle & - & once daily for 14 days & 5 \\
\hline Disease+vehicle & - & once daily for 14 days & 5 \\
\hline Disease+Lycogen-1 & $50 \mathrm{mg} / \mathrm{kg}$ & once daily for 14 days & 5 \\
\hline Disease+Lycogen-2 & $100 \mathrm{mg} / \mathrm{kg}$ & once daily for 14 days & 5 \\
\hline Disease+Lycogen-3 & $200 \mathrm{mg} / \mathrm{kg}$ & once daily for 14 days & 5 \\
\hline
\end{tabular}

Table 1: Study design.

\begin{tabular}{|c|c|c|c|}
\hline Treatment & \multicolumn{2}{|c|}{ Insulin resistance index } & p value \\
\hline & Day 0 & Day 14 & \\
\hline Blank+Vehicle & $3.9 \pm 1.8$ & $2.8 \pm 0.8$ & 0.115 \\
\hline Disease+Vehicle & $7.8 \pm 1.0$ & $7.7 \pm 1.1$ & 0.814 \\
\hline Disease+Lycogen $50 \mathrm{mg} / \mathrm{kg}$ & $8.0 \pm 2.7$ & $6.1 \pm 1.8$ & 0.021 \\
\hline Disease+Lycogen $100 \mathrm{mg} / \mathrm{kg}$ & $7.9 \pm 1.1$ & $7.0 \pm 1.2$ & 0.389 \\
\hline Disease+Lycogen $200 \mathrm{mg} / \mathrm{kg}$ & $10.2 \pm 1.8$ & $5.9 \pm 1.4$ & 0.003 \\
\hline
\end{tabular}

$\mathrm{p}=0.142, \mathrm{p}=0.239$

HOMA-IR (insulin resistance) index $=$ insulin $(\mu \mathrm{U} / \mathrm{mL} \times$ glucose $(\mathrm{mmol} / \mathrm{L}) / 22.5$

Table 2: Insulin resistance index in day 0 and day 14 of Lycogen treatment. There was no significant difference between each disease group at day $0(p=0.142)$ or day $14(p=0.239)$ 
Citation: Wang CC, Liu WS, Chang FH, Tsai PY, Tsai MK, et al. (2014) Rhodobacter sphaeroides Extract Improves Glucose Homeostasis in Streptozotocin-Induced Diabetic Mice. J Microb Biochem Technol 6: 038-042. doi:10.4172/1948-5948.1000119

\section{References}

1. Vaz JA, Patnaik A (2012) Diabetes mellitus: Exploring the challenges in the drug development process. Perspect Clin Res 3: 109-112.

2. Ceriello A, Motz E (2004) Is oxidative stress the pathogenic mechanism underlying insulin resistance, diabetes, and cardiovascular disease? The common soil hypothesis revisited. Arterioscler Thromb Vasc Biol 24: 816-823.

3. Paolisso G, Giugliano D (1996) Oxidative stress and insulin action: is there a relationship? Diabetologia 39: 357-363.

4. Oberley LW (1988) Free radicals and diabetes. Free Radic Biol Med 5: 113124

5. Tanaka Y, Gleason CE, Tran PO, Harmon JS, Robertson RP (1999) Prevention of glucose toxicity in HIT-T15 cells and Zucker diabetic fatty rats by antioxidants. Proc Natl AcadSci U S A 96: 10857-10862.

6. Henriksen EJ, Diamond-Stanic MK, Marchionne EM (2011) Oxidative stress and the etiology of insulin resistance and type 2 diabetes. Free Radic Biol Med 51: 993-999.

7. Vichaiwong K, Henriksen EJ, Toskulkao C, Prasannarong M, Bupha-Intr T, et al. (2009) Attenuation of oxidant-induced muscle insulin resistance and p38 MAPK by exercise training. Free Radic Biol Med 47: 593-599.

8. Kaneto H, Matsuoka TA, Katakami N, Kawamori D, Miyatsuka T, et al. (2007) Oxidative stress and the JNK pathway are involved in the development of type 1 and type 2 diabetes. Curr Mol Med7: 674-686.

9. Hirosumi J, Tuncman G, Chang L, Gorgun CZ, Uysal KT, et al. (2002) A central role for JNK in obesity and insulin resistance. Nature 420: 333-336.

10. Yang R, Wilcox DM, Haasch DL, Jung PM, Nguyen PT, et al. (2007) Liverspecific knockdown of JNK1 up-regulates proliferator-activated receptor gamma coactivator 1 beta and increases plasma triglyceride despite reduced glucose and insulin levels in diet-induced obese mice. J Biol Chem 282: 2276522774.

11. Bates CJ, Lean ME, Mansoor MA, Prentice A (2004) Nutrient intakes; biochemical and risk indices associated with Type 2 diabetes and glycosylated haemoglobin, in the British National Diet and Nutrition Survey of people aged 65 years and over. Diabet Med 21: 677-684.

12. Ford ES, Will JC, Bowman BA, Narayan KM (1999) Diabetes mellitus and serum carotenoids: findings from the Third National Health and Nutrition Examination Survey. Am J Epidemiol 149: 168-176.

13. Armstrong AM, Chestnutt JE, Gormley MJ, Young IS (1996) The effect of dietary treatment on lipid peroxidation and antioxidant status in newly diagnosed noninsulin dependent diabetes. Free Radic Biol Med 21: 719-726.

14. Suzuki K, Ito Y, Nakamura S, Ochiai J, Aoki K (2002) Relationship between serum carotenoids and hyperglycemia: a population-based cross-sectional study. J Epidemiol 12: 357-366.

15. Polidori MC, Mecocci P, Stahl W, Parente B, Cecchetti R, et al. (2000) Plasma levels of lipophilic antioxidants in very old patients with type 2 diabetes. Diabetes Metab Res Rev 16: 15-19.

16. Bose KS, Agrawal BK (2006) Effect of long term supplementation of tomatoes (cooked) on levels of antioxidant enzymes, lipid peroxidation rate, lipid profile and glycatedhaemoglobin in Type 2 diabetes mellitus. West Indian Med J55: 274-278.

17. Chen Y, Graham A, Potter W, Morgan J, Vaughan L, et al. (2002) Bacteriopurpurinimides: highly stable and potent photosensitizers for photodynamic therapy. J Med Chem 45: 255-258.

18. Hunter CN, Hundle BS, Hearst JE, Lang HP, Gardiner AT, et al. (1994) Introduction of new carotenoids into the bacterial photosynthetic apparatus by combining the carotenoid biosynthetic pathways of Erwiniaherbicola and Rhodobactersphaeroides. J Bacteriol 176: 3692-3697.

19. Liu WS, Chen MC, Chiu KH, Wen ZH, Lee CH (2012) Amelioration of dextran sodium sulfate-induced colitis in mice by Rhodobacter sphaeroides extract. Molecules 17: 13622-13630.

20. Liu WS, Kuan YD, Chiu KH, Wang WK, Chang FH, et al. (2013) The extract of Rhodobactersphaeroidesinhibits melanogenesis through the MEK/ERK signaling pathway. Mar Drugs 11: 1899-1908.

21. Braca A, De Tommasi N, Di Bari L, Pizza C, Politi M, et al. (2001) Antioxidant principles from Bauhinia tarapotensis. J Nat Prod 64: 892-895.

22. Di Mascio P, Kaiser S, Sies H (1989) Lycopene as the most efficient biological carotenoid singlet oxygen quencher. Arch Biochem Biophys 274: 532-538.

23. Ylonen K, Alfthan G, Groop L, Saloranta C, Aro A, et al. (2003) Dietary intakes and plasma concentrations of carotenoids and tocopherols in relation to glucose metabolism in subjects at high risk of type 2 diabetes: the Botnia Dietary Study. Am J ClinNutr 77: 1434-1441. 